\title{
Vertical Distribution of Micronutrient Cations in the Orange (Citrus reticulata) Orchard, Tamenglong District, Manipur (India)
}

\author{
Laikhuram Banarjee Singh, Herojit Singh Athokpam*, Rajkumar Kumarjit Singh, \\ K. Nandini Devi, Edwin Luikham and N. Okendro Singh \\ College of Agriculture, CAU, Imphal, Manipur, India \\ *Corresponding author
}

\section{A B S T R A C T}

Keywords

Micronutrients, Orange orchard, Profile, Multiple regression

Article Info

Accepted:

10 June 2019

Available Online:

10 July 2019

\begin{abstract}
Vertical distribution of DTPA-extractable micronutrient cations ( $\mathrm{Fe}, \mathrm{Cu}, \mathrm{Mn}$ and $\mathrm{Zn}$ ) and its correlation with several physico-chemical properties of soils in fifteen orange orchards of Tamenglong district, Manipur was studied. Most of the upper soil layer had higher DTPA-extractable micronutrient cations ( $\mathrm{Fe}, \mathrm{Cu}, \mathrm{Mn}$ and $\mathrm{Zn}$ ) content than the lower horizons. In the profiles, the value of DTPA- extractable micronutrients ( $\mathrm{Fe}, \mathrm{Cu}, \mathrm{Mn}$ and $\mathrm{Zn}$ ) ranged from 18.62 to $45.12 \mathrm{mg} \mathrm{kg}^{-1}, 0.12$ to $1.26 \mathrm{mg} \mathrm{kg}^{-1}, 3.42$ to $44.33 \mathrm{mg} \mathrm{kg}^{-1}$ and 0.16 to $1.36 \mathrm{mg} \mathrm{kg}^{-1}$, respectively. The DTPA-extractable $\mathrm{Fe}$ and $\mathrm{Mn}$ were found to be sufficiently available in all the profiles whereas, $\mathrm{Cu}$ was found adequate in most of the surface horizon $(0-20 \mathrm{~cm})$ in most of the soil samples. However, Zn deficiency occurred in $55.56 \%$ of the soil sample. Multiple regression analysis showed that the DTPAextractable micronutrient cations ( $\mathrm{Fe}, \mathrm{Cu}, \mathrm{Mn}$ and $\mathrm{Zn}$ ) content in the soils were influenced by $\mathrm{pH}, \mathrm{OC}, \mathrm{EC}, \mathrm{Mg}$, silt, $\mathrm{K}$ and clay to the degree of $50.1,25.7$ and $60.5 \%$ in the surface horizon but their influenced were significant only by soil OC and silt.
\end{abstract}

\section{Introduction}

The word "micronutrients" represents some essential nutrients ( $\mathrm{Fe}, \mathrm{Mn}, \mathrm{Zn}, \mathrm{Cu}, \mathrm{B}, \mathrm{Mo}, \mathrm{Ni}$ and $\mathrm{Cl}$ ) that are required in very small quantities for the growth and development of plants. Micronutrients are very important for maintaining soil health and also in increasing productivity of crops (Rattan et al., 2009). Through their involvement in various enzymes and other physiologically active molecules, these micronutrients are important for gene expression, biosynthesis of proteins, nucleic acids, growth substances, chlorophyll and secondary metabolites, metabolism of carbohydrates and lipids, stress tolerance, etc. (Singh, 2004, Rengel, 2007 and Gao et al., 2008).

Less nutrient management practices contribute towards exhaustion of micronutrients from the soil and micronutrients are bound to become a limiting factor. The deficiency of micronutrients has become major constraint to productivity, stability and sustainability of soils (Bell and Dell, 2008). Deficiency of micronutrients may either be primary, due to their low total 
contents or secondary, caused by soil factors reducing their availability to plants. Improper nutrient management has led to the emergence of multi-nutrient deficiencies in Indian soils (Sharma, 2008). Moreover, continuous negligence of micronutrient application and avoidance of organic manures are the major causes of deficiency of micronutrients (Srivastava et al., 2017).

Citrus is claimed to have originated in south China and Cathaysian ancient continent including Sichuan, Kangdian, South of Yangtze river and Indo-China peninsula, then dispersed into India, Africa and Australia according to the theories of continental drift, the ecological and geological vicissitude. Agro-meteorologically, citrus is observed more comfortable under tropical and subtropical and climate representing $24-38^{0}$ at either side of equator with hot days/cool nights and less exposed to prolonged freezing temperature. The highest quantum of production harvested globally is represented by soil orders viz. Alfisol, Oxisol, Ultisol, Entisol and Inceptisol (Srivastava and Singh, $2002 b)$. The current average productivity of citrus orchards in India is 8.9 tons $\mathrm{ha}^{-1}$ compared to 4.52 tons ha $^{-1}$ obtained in NorthEast India (Srivastava and Singh, 2002a), the region historically believed to have witnessed the dissemination of citrus to other parts of the world. Cultivation of Khasi mandarin (Citrus reticulata Blanco.) in North-East India is mainly confined to mid-hills up to an elevation of $1200 \mathrm{~m}$ above mean sea level under humid tropical climate. Manipur has a geographical area of 22,327 sq. km. which constitutes $0.7 \%$ of the total land surface of India. Ninety per cent of the total geographical area of the state i.e. 20,097 sq. $\mathrm{km}$. is covered by hills. Around 3,838 hectares of land are under orange cultivation in Manipur. Khasi Mandarin is a variety of orange produced in Tamenglong, a district located $140 \mathrm{kms}$ from Imphal and lies at coordinates bearing $24^{\circ} 59^{\prime} \mathrm{N} \quad 9^{\circ} 29^{\prime} \mathrm{E}$ Tamenglong district is known as the "Orange Bowl" of the state. The district contributes over $50 \%$ of the state's annual total orange production of nearly 10,000 to 11,000 metric tons. The total geographical area of Tamenglong is $4391 \mathrm{~km}^{2}$. The climate here is humid and sub-tropical type. The climate and soil here are well suited for the production of orange. The knowledge of pedogenic distribution of micronutrients is, therefore, important as many plant roots penetrate to the sub-surface layers and draw a part of the nutrient requirement from the sub-surface layers. However, there is little or no information regarding status and distribution of micronutrients in soils under orange cultivation in the district. Keeping in view of the close relationship between soil properties and micronutrient availability, the present study was undertaken to analyze the depthwise distribution of micronutrients $(\mathrm{Fe}, \mathrm{Cu}$, $\mathrm{Mn}$ and $\mathrm{Zn}$ ) in the soil and to study the relationship of the micronutrients $(\mathrm{Fe}, \mathrm{Cu}, \mathrm{Mn}$ and $\mathrm{Zn}$ ) with the physico-chemical properties of soil.

\section{Materials and Methods}

The experimental location is in Tamenglong district of Manipur which has an area of 4391 $\mathrm{km}^{2}$ which constitutes $19.66 \%$ of the total geographical area of the state. It is located in the north-western part of Manipur and lies at coordinates bearing $24^{\circ} 59^{\prime} \mathrm{N} 93^{\circ} 29^{\prime} \mathrm{E}$. The altitude is $1260 \mathrm{~m}$ above MSL. It has humidity range of 76 to $96 \%$ and temperature of $4^{\circ} \mathrm{C}$ at minimum and $31^{\circ} \mathrm{C}$ at maximum. The climate here is humid and sub-tropical type. The climate and soil here are well suited for the production of orange. In Tamenglong, the average annual temperature is $18.5^{\circ} \mathrm{C}$ and about $3336 \mathrm{~mm}$ of precipitation falls annually. Generally, the main soils found in the district are red loamy soil, red sandy soil and red gravelly soil. The experimental sites under 
study were mainly dominated by orange orchards. Soil samples were collected from fifteen different orange orchards of Tamenglong district. From each site, three samples were collected depth wise up to 60 $\mathrm{cm}$ at an interval of $20 \mathrm{~cm}$ from the surface i.e. $0-20,20-40$ and 40-60, respectively. Totally, 45 soil samples were collected for study. The collected soil samples were thoroughly air dried in shade and ground with a wooden mortar and pestle and passed through $2 \mathrm{~mm}$ sieve for analysis. The collected samples were processed and analyzed following standard procedures for mechanical analysis using Bouyoucos hydrometer method (Bouyoucos, 1951); soil $\mathrm{pH}$ and EC using (1: 2.5) soil: water suspension (Jackson 1973); organic carbon by the Walkley and Black rapid titration method (Walkley and Black 1934); CEC by leaching with $1 \mathrm{~N}$ ammonium acetate (Borah et al., 1987). The soil sample were determined for available N (Subbiah and Asija, 1956); available P (Bray and Kurtz 1945); available $\mathrm{K}, \mathrm{Ca}$ and $\mathrm{Mg}$ of soil were extracted with neutral normal ammonium acetate as outlined by Chopra and Kanwar (1976) and DTPAextractable $\mathrm{Zn}, \mathrm{Cu}, \mathrm{Mn}$ and $\mathrm{Fe}$ following standard procedures as outlined by (Lindsay and Norvell, 1978). The relationship between various soil physico-chemical properties and micronutrients distribution were established by using simple correlation coefficient. Multiple regression equations were computed between DTPA- extractable micronutrients and soil properties by adopting statistical procedures (Panse and Sukhatme, 1985).

\section{Results and Discussion}

The physico-chemical properties as well as DTPA-extractable $\mathrm{Fe}, \mathrm{Cu}, \mathrm{Mn}$ and $\mathrm{Zn}$ are presented in table 1 and 2 . There was no exact pattern in the distribution of clay, silt and sand with the depth of soil profiles. Clay, silt and sand fractions in the soils ranged from
37.6 to $53.1,13.4$ to 26.0 and 26.3 to 44.6 per cent, respectively. The samples were very strongly acidic ( $\mathrm{pH}$ 4.68) to slightly acidic (pH 6.10) in reaction. EC values ranging from 0.02 to $0.27 \mathrm{dSm}^{-1}$. Organic carbon content ranged from 0.46 to 1.58 per cent. Cation exchange capacity (CEC) varied from 10.60 to $20.00\left[\mathrm{cmol}\left(\mathrm{p}^{+}\right) \mathrm{kg}^{-1}\right]$ soil.

The available nitrogen, phosphorus and potassium content in the soil profiles varied from 138.9 to $536.5 \mathrm{~kg} \mathrm{ha}^{-1}, 10.2$ to $25.4 \mathrm{~kg}$ $\mathrm{P}_{2} \mathrm{O}_{5} \mathrm{ha}^{-1}$ and 81.4 to $242.5 \mathrm{~kg} \mathrm{~K}_{2} \mathrm{O} \mathrm{ha}{ }^{-1}$, respectively. Exchangeable $\mathrm{Ca}^{++}$content ranged from 0.3 to 0.9 and $\mathrm{Mg}^{++}$from 0.3 to $1.4\left[\mathrm{cmol}(\mathrm{p}+) \mathrm{kg}^{-1}\right]$. The region is high rainfall area which might be due to intense the leaching action of the bases from the surface layers. The content of these nutrients decreased with increase in depth in most of the studied profiles. Similar results were also reported by Athokpam et al., (2016) and Athokpam et al., (2018) in the soils of Ukhrul and Tamenglong districts of Manipur, respectively.

\section{Iron $(\mathbf{F e})$}

The DTPA-extractable Fe content of the soil samples was fairly high with a value ranging from 18.62 to $45.12 \mathrm{mg} \mathrm{kg}^{-1}$ soil in the orange orchard soils of Tamenglong district of Manipur. The iron content of these soils is high because, the solubility of ferric and ferrous iron is much lower at high $\mathrm{pH}$ than at low $\mathrm{pH}$ and leaching of exchangeable bases. In view of critical limit of $4.5 \mathrm{mg} \mathrm{Fe} \mathrm{kg}^{-1}$ soil (Lindsay and Norvell, 1978), all the samples were highly sufficient in available Fe. DTPA$\mathrm{Fe}$ content in the profile showed significant positive coefficient with $\mathrm{OC}\left(\mathrm{r}=0.531^{*}\right)$ and $\left(\mathrm{r}=0.523^{*}\right)$ in the $1^{\text {st }}$ and $2^{\text {nd }}$ layer, respectively and negatively significantly correlated with $\mathrm{pH}\left(\mathrm{r}=-0.626^{* *}\right)$ and $\mathrm{EC}(\mathrm{r}=-$ $0.527 * *)$ in the $1^{\text {st }}$ layer as well as with $\mathrm{pH}$ $\left(\mathrm{r}=-0.513^{*}\right)$ in the $2^{\text {nd }}$ layer. It showed 
significant regression coefficient with OC $(20.028 *)$ at $2^{\text {nd }}(20-40 \mathrm{~cm})$ layer. Multiple correlation and regression analyses indicated that 50.1, 37.1 and 29.3 per cent variability in the profile was due to the simultaneous effect of $\mathrm{pH}, \mathrm{EC}, \mathrm{OC}$ and $\mathrm{Mg}$ in the soil. The surface layer soil contained more available $\mathrm{Fe}$ than those in lower depth and showed a decreasing pattern along with depth except for few samples. These findings are in agreement with the works of Sen et al., (1997), Gupta et al., (2003), Sharma et al., (2003), Pati and Mukhopadhyay (2011), Athokpam et al., (2013), Athokpam et al., (2016), Athokpam et al., (2018) and Singh et al., (2018).

\section{Copper $(\mathbf{C u})$}

The DTPA-Cu content varied from 0.12 to $1.26 \mathrm{mg} \mathrm{kg}^{-1}$ soils. Considering $0.20 \mathrm{mg} \mathrm{Cu}$ $\mathrm{kg}^{-1}$ soil as critical limit (Lindsay and Norvell, 1978), most of the samples, except a few in the sub-surface horizons, were well supplied with available $\mathrm{Cu}$. Similar findings were also reported by Sen et al., (1997). Higher DTPAextractable $\mathrm{Cu}$ content was observed in surface soil than those of lower layers. This might be due to higher biological activity and organic carbon content in the surface layers (Murthy et al., 1997). Available $\mathrm{Cu}$ content decreased with increase in depth in most profiles. These results were also conveyed by Gupta et al., (2003), Verma et al., (2007b), Athokpam, et al., (2016), Singh and Athokpam (2018) and Athokpam et al., (2018). Nevertheless, the study observed that there was an irregular distribution of DTPAextractable $\mathrm{Cu}$ with depth in a few soil samples. This finding is in accordance with the work of Kumar et al., (1996) and Satyavathi and Reddy (2004). The present study revealed that there was no significant multiple correlation and regression analyses which indicated no per cent variability of available soil $\mathrm{Cu}$ content in each layer could be attributed to the effect of soil properties.

\section{Manganese (Mn)}

The range of Mn availability varied from 3.42 to $44.33 \mathrm{mg} \mathrm{kg}^{-1}$ soil. Considering critical value of $1.0 \mathrm{mg} \mathrm{Mn} \mathrm{kg}^{-1}$ soil (Lindsay and Norvell, 1978), all the samples were well distributed with DTPA-extractable Mn. Sen $e t$ al., (1997), Sarkar et al., (2002), Athokpam et al., (2013), Athokpam et al., (2016), Athokpam et al., (2018) reported the abundance of DTPA - Mn in soils of Manipur. The high amount of Mn in the soil might be due to the solubility of this cation is higher at low $\mathrm{pH}$. The distribution did not trail any regular trend in the entire sample. Irregular distribution of DTPA-extractable $\mathrm{Mn}$ with depth was observed. There is a similar finding as compared to Rajkumar et al., (1990), Athokpam et al., (2013), Athokpam et al., (2016), Athokpam et al., (2018) and Singh and Athokpam (2018). DTPA-extractable Mn content in the soil profile showed positive and significant correlated with soil OC $\left(\mathrm{r}=0.507^{*}\right)$ and $\left(\mathrm{r}=0.569^{*}\right)$ in the $1^{\text {st }}$ layer and $2^{\text {nd }}$ layer, respectively. Only OC (19.400* and 18.707*) content in the soils significantly correlated with $\mathrm{Mn}$ content in the $2^{\text {nd }}$ and $3^{\text {rd }}$ layers. Multiple correlation and regression analyses indicated that 25.7, 32.4 and 24.9 per cent variability in available $\mathrm{Mn}$ content were due to the effect of OC content in the soils (Table 3).

\section{Zinc (Zn)}

DTPA-extractable $\mathrm{Zn}$ in the soil profile varied from 0.24 to $1.36 \mathrm{mg} \mathrm{kg}^{-1}$ soil. DTPAextractable $\mathrm{Zn}$, like other soil nutrients, accumulates more in surface layers than subsurface layers and goes on decreasing with the increase in depth. This might be due to the $\mathrm{Zn}$ interacts with organic matter in the soils, thus formed both soluble and insoluble Zn-organic complexes, as studied soils are high organic matter content in the surface soils. Pati and 
Mukhopadhyay, (2011), Athokpam et al., (2013), Athokpam et al., (2016), Athokpam et al., (2018) and Singh and Athokpam (2018) reported similar findings. In view of the critical limit of $0.6 \mathrm{mg} \mathrm{Zn} \mathrm{kg}{ }^{-1}$ soil (Lindsay and Norvell, 1978), Zn which deficiency occurred in $55.56 \%$ soils and required $\mathrm{Zn}$ fertilization for better yield of orange. Sen et al., (1997) and Sarkar et al., (2002) also observed inadequate or marginal adequate in available $\mathrm{Zn}$ in soils of Manipur. DTPA-Zn content in the soil showed positive and significantly related with clay $\left(\mathrm{r}=0.494^{*}\right)$ and
$\mathrm{K} \quad\left(\mathrm{r}=0.501^{*}\right)$ in the $1^{\mathrm{st}}$ and $3^{\mathrm{rd}}$ layer, respectively and negatively significantly related with silt content $(\mathrm{r}=-0.709 * *)$. Multiple correlation and regression analyses revealed that 60.5 and 24.8 per cent variability in available $\mathrm{Zn}$ content may be due to the simultaneous effect of the various soil properties such as silt and clay and $\mathrm{K}$ included in the $1^{\text {st }}$ and $3^{\text {rd }}$ profiles, respectively. Only silt content in the soils significantly correlated with $\mathrm{Mn}$ content in the surface layer $\left(0.076^{*}\right)$ (Table 4-6).

Table.1 Physico-chemical properties of soil profiles

\begin{tabular}{|c|c|c|c|c|c|c|c|c|c|c|c|c|c|c|}
\hline Sample & $\begin{array}{c}\text { Depth } \\
(\mathrm{cm})\end{array}$ & $\begin{array}{c}\text { Clay } \\
\%\end{array}$ & $\begin{array}{c}\text { Silt } \\
\%\end{array}$ & $\begin{array}{c}\text { Sand } \\
\%\end{array}$ & Texture & $\begin{array}{c}\text { pH } \\
(1: 2.5)\end{array}$ & $\begin{array}{c}\text { E.C } \\
\left(\begin{array}{c}\text { dSm } \\
-1\end{array}\right)\end{array}$ & $\begin{array}{c}\text { CEC } \\
{[\mathbf{C m o l}} \\
(\mathbf{p}+) \\
\left.\mathbf{k g}^{-1}\right]\end{array}$ & $\begin{array}{l}\text { OC } \\
(\%)\end{array}$ & $\begin{array}{c}\text { N } \\
\text { Kg/ha }\end{array}$ & $\begin{array}{c}\mathrm{P}_{2} \mathrm{O}_{5} \\
\mathrm{Kg} / \mathrm{h} \\
\mathbf{a}\end{array}$ & $\begin{array}{c}\mathrm{K}_{2} \mathrm{O} \\
\mathrm{Kg} / \mathrm{ha}\end{array}$ & $\begin{array}{l}\mathrm{Ca}^{++} \\
{[\mathrm{Cmol}} \\
(\mathbf{p}+) \\
\left.\mathbf{k g}^{-1}\right]\end{array}$ & $\begin{array}{l}\mathbf{M g}^{++} \\
{[\mathrm{Cmol}} \\
(\mathbf{p}+) \\
\left.\mathbf{k g}^{-1}\right]\end{array}$ \\
\hline \multicolumn{15}{|c|}{ 1.Taningjam } \\
\hline & $0-20$ & 47.1 & 22.2 & 30.7 & Clay & 4.90 & 0.08 & 14.60 & 1.36 & 512.7 & 21.3 & 198.3 & 0.9 & 0.5 \\
\hline & $20-40$ & 51.0 & 21.9 & 27.1 & Clay & 5.04 & 0.04 & 14.90 & 0.98 & 430.5 & 18.1 & 118.1 & 0.7 & 0.5 \\
\hline & $40-60$ & 46.8 & 19.0 & 34.2 & Clay & 5.13 & 0.06 & 12.50 & 0.72 & 352.5 & 15.5 & 106.0 & 0.5 & 0.5 \\
\hline \multicolumn{15}{|c|}{ 2.Dailong-1 } \\
\hline & $0-20$ & 44.8 & 19.0 & 36.2 & Clay & 4.95 & 0.22 & 12.40 & 1.38 & 338.9 & 16.2 & 196.3 & 0.8 & 0.6 \\
\hline & $20-40$ & 43.1 & 13.4 & 43.5 & Clay & 5.16 & 0.15 & 11.00 & 1.10 & 286.6 & 14.0 & 142.2 & 0.6 & 0.8 \\
\hline & $40-60$ & 40.8 & 17.5 & 41.7 & Clay & 5.27 & 0.11 & 10.80 & 0.86 & 225.9 & 12.8 & 106.1 & 0.4 & 0.6 \\
\hline \multicolumn{15}{|c|}{ 3.Dailong-2 } \\
\hline & $0-20$ & 39.1 & 24.2 & 36.7 & $\begin{array}{l}\text { Clay } \\
\text { loam }\end{array}$ & 4.92 & 0.12 & 16.40 & 1.08 & 348.2 & 17.3 & 206.3 & 0.6 & 1.1 \\
\hline & $20-40$ & 49.9 & 16.7 & 33.4 & Clay & 5.08 & 0.05 & 17.20 & 1.02 & 262.4 & 15.1 & 136.1 & 0.4 & 1.2 \\
\hline & $40-60$ & 47.5 & 22.3 & 30.2 & Clay & 5.22 & 0.08 & 16.80 & 0.78 & 236.6 & 13.6 & 116.9 & 0.4 & 1.0 \\
\hline \multicolumn{15}{|l|}{ 4.Bhalok } \\
\hline & $0-20$ & 41.2 & 22.2 & 36.6 & Clay & 4.68 & 0.10 & 19.34 & 1.58 & 536.5 & 23.8 & 186.3 & 0.6 & 0.9 \\
\hline & $20-40$ & 38.9 & 21.6 & 39.5 & $\begin{array}{l}\text { Clay } \\
\text { loam }\end{array}$ & 4.90 & 0.11 & 18.30 & 1.02 & 404.6 & 19.6 & 108.1 & 0.5 & 0.8 \\
\hline & $40-60$ & 38.7 & 24.8 & 36.5 & $\begin{array}{l}\text { Clay } \\
\text { loam }\end{array}$ & 5.39 & 0.08 & 16.70 & 0.94 & 346.7 & 16.1 & 96.0 & 0.4 & 0.9 \\
\hline \multicolumn{15}{|c|}{ 5.Tamei Road } \\
\hline & $0-20$ & 42.6 & 22.5 & 34.9 & Clay & 4.92 & 0.11 & 16.80 & 1.29 & 452.8 & 19.0 & 144.8 & 0.4 & 0.6 \\
\hline & $20-40$ & 48.0 & 22.7 & 29.3 & Clay & 5.16 & 0.10 & 17.40 & 1.04 & 344.9 & 16.8 & 133.2 & 0.4 & 0.5 \\
\hline & $40-60$ & 51.8 & 19.3 & 28.9 & Clay & 5.28 & 0.06 & 16.20 & 0.78 & 264.4 & 15.2 & 92.1 & 0.4 & 0.3 \\
\hline \multicolumn{15}{|c|}{ 6.Kahulong-1 } \\
\hline & $0-20$ & 49.4 & 24.3 & 26.3 & Clay & 4.90 & 0.17 & 17.30 & 0.94 & 415.1 & 20.5 & 194.9 & 0.6 & 0.8 \\
\hline
\end{tabular}




\begin{tabular}{|c|c|c|c|c|c|c|c|c|c|c|c|c|c|c|}
\hline & $20-40$ & 52.5 & 16.5 & 31.0 & Clay & 5.17 & 0.13 & 19.50 & 0.84 & 322.1 & 18.3 & 118.8 & 0.5 & 0.5 \\
\hline & $40-60$ & 44.5 & 15.3 & 40.2 & Clay & 5.17 & 0.12 & 16.17 & 0.50 & 241.3 & 16.2 & 98.7 & 0.5 & 0.4 \\
\hline \multicolumn{15}{|c|}{ 7.Kahulong-2 } \\
\hline & $0-20$ & 45.5 & 18.6 & 35.9 & Clay & 4.87 & 0.06 & 13.60 & 1.30 & 400.1 & 18.6 & 208.0 & 0.8 & 0.6 \\
\hline & $20-40$ & 46.4 & 17.9 & 35.7 & Clay & 5.13 & 0.09 & 13.90 & 1.07 & 312.1 & 15.4 & 124.9 & 0.6 & 0.4 \\
\hline & $40-60$ & 45.9 & 16.5 & 37.6 & Clay & 5.22 & 0.09 & 11.90 & 0.64 & 251.3 & 11.9 & 118.7 & 0.3 & 0.6 \\
\hline \multicolumn{15}{|c|}{ 8.Kahulong-3 } \\
\hline & $0-20$ & 48.8 & 17.8 & 33.4 & Clay & 4.84 & 0.11 & 15.20 & 1.33 & 458.8 & 25.4 & 212.7 & 0.5 & 0.8 \\
\hline & $20-40$ & 41.0 & 17.3 & 41.7 & Clay & 5.06 & 0.14 & 20.00 & 1.16 & 370.8 & 18.3 & 142.6 & 0.5 & 0.8 \\
\hline & $40-60$ & 49.4 & 17.2 & 33.4 & Clay & 5.18 & 0.07 & 16.40 & 0.72 & 284.7 & 11.2 & 94.2 & 0.7 & 0.7 \\
\hline \multicolumn{15}{|c|}{ 9.Farmland-1 } \\
\hline & $0-20$ & 41.5 & 25.9 & 32.6 & Clay & 4.98 & 0.02 & 13.20 & 0.94 & 334.4 & 16.4 & 130.9 & 0.5 & 0.7 \\
\hline & $20-40$ & 46.6 & 21.7 & 31.7 & Clay & 5.09 & 0.06 & 13.60 & 0.75 & 244.4 & 15.3 & 107.8 & 0.4 & 0.3 \\
\hline & $40-60$ & 41.5 & 19.0 & 39.8 & Clay & 5.27 & 0.06 & 13.40 & 0.63 & 158.6 & 12.7 & 98.7 & 0.4 & 0.4 \\
\hline \multicolumn{15}{|c|}{ 10.Farmland-2 } \\
\hline & $0-20$ & 37.8 & 22.1 & 40.1 & $\begin{array}{l}\text { Clay } \\
\text { loam }\end{array}$ & 4.97 & 0.17 & 15.80 & 1.02 & 436.8 & 19.9 & 170.3 & 0.4 & 0.6 \\
\hline & $20-40$ & 37.6 & 23.5 & 38.9 & $\begin{array}{l}\text { Clay } \\
\text { loam }\end{array}$ & 5.13 & 0.06 & 14.30 & 0.52 & 355.9 & 15.9 & 117.1 & 0.3 & 0.4 \\
\hline & $40-60$ & 41.2 & 19.0 & 39.8 & Clay & 5.39 & 0.09 & 13.70 & 0.48 & 284.2 & 11.1 & 94.2 & 0.4 & 0.3 \\
\hline \multicolumn{15}{|c|}{ 11.Keikao-1 } \\
\hline & $0-20$ & 45.2 & 26.0 & 28.8 & Clay & 4.91 & 0.16 & 13.80 & 1.26 & 501.7 & 18.8 & 230.5 & 0.7 & 0.8 \\
\hline & $20-40$ & 53.1 & 15.4 & 31.5 & Clay & 5.12 & 0.08 & 14.30 & 0.68 & 390.6 & 16.7 & 168.3 & 0.5 & 0.5 \\
\hline & $40-60$ & 52.6 & 17.8 & 29.6 & Clay & 5.44 & 0.10 & 13.10 & 0.46 & 282.7 & 13.1 & 116.2 & 0.5 & 0.6 \\
\hline \multicolumn{15}{|c|}{ 12.Keikao-2 } \\
\hline & $0-20$ & 46.3 & 20.0 & 33.7 & Clay & 4.91 & 0.14 & 14.80 & 0.96 & 285.6 & 17.9 & 224.4 & 0.8 & 0.9 \\
\hline & $20-40$ & 47.7 & 14.4 & 37.9 & Clay & 4.99 & 0.27 & 13.00 & 0.74 & 182.7 & 13.7 & 119.2 & 0.7 & 0.6 \\
\hline & $40-60$ & 50.2 & 18.1 & 31.7 & Clay & 5.05 & 0.12 & 10.60 & 0.52 & 138.9 & 10.2 & 114.1 & 0.5 & 0.5 \\
\hline \multicolumn{15}{|c|}{ 13.Tamenglong Headquarter } \\
\hline & $0-20$ & 43.0 & 21.6 & 35.4 & Clay & 4.72 & 0.20 & 16.00 & 1.34 & 378.4 & 17.0 & 140.7 & 0.7 & 1.4 \\
\hline & $20-40$ & 39.5 & 18.6 & 41.9 & $\begin{array}{l}\text { Clay } \\
\text { loam }\end{array}$ & 5.10 & 0.14 & 15.60 & 1.32 & 312.3 & 14.8 & 90.5 & 0.5 & 0.7 \\
\hline & $40-60$ & 40.1 & 15.3 & 44.6 & Clay & 6.10 & 0.11 & 14.80 & 0.80 & 252.6 & 12.3 & 81.4 & 0.7 & 0.8 \\
\hline \multicolumn{15}{|c|}{ 14.C-Center } \\
\hline & $0-20$ & 40.2 & 20.8 & 39.0 & Clay & 4.77 & 0.06 & 18.00 & 1.46 & 340.0 & 14.1 & 242.5 & 0.5 & 1.0 \\
\hline & $20-40$ & 46.8 & 16.2 & 37.0 & Clay & 5.13 & 0.10 & 18.80 & 1.14 & 336.0 & 13.9 & 130.3 & 0.4 & 0.7 \\
\hline & $40-60$ & 45.5 & 22.9 & 31.6 & Clay & 5.17 & 0.06 & 15.00 & 0.84 & 251.2 & 11.3 & 118.2 & 0.4 & 0.6 \\
\hline \multicolumn{15}{|l|}{ 15.Azuram } \\
\hline & $0-20$ & 38.8 & 22.3 & 38.9 & $\begin{array}{l}\text { Clay } \\
\text { loam }\end{array}$ & 4.98 & 0.08 & 13.80 & 1.02 & 398.7 & 15.9 & 194.9 & 0.6 & 0.7 \\
\hline & $20-40$ & 45.5 & 20.1 & 35.4 & Clay & 5.04 & 0.07 & 13.00 & 0.82 & 262.8 & 12.8 & 102.7 & 0.5 & 0.4 \\
\hline & $40-60$ & 44.6 & 20.3 & 35.1 & Clay & 5.12 & 0.12 & 12.80 & 0.76 & 239.9 & 12.2 & 84.6 & 0.5 & 0.5 \\
\hline
\end{tabular}


Table.2 Distribution of available DTPA-extractable micronutrients of soil profile

\begin{tabular}{|c|c|c|c|c|c|}
\hline \multirow[t]{2}{*}{ Sample } & \multirow{2}{*}{$\begin{array}{c}\text { Depth } \\
\text { (cm) }\end{array}$} & \multicolumn{4}{|c|}{ DTPA - Extractable micronutrients $\left(\mathrm{mg} \mathrm{kg}^{-1}\right)$} \\
\hline & & $\mathrm{Fe}$ & $\mathrm{Cu}$ & $\mathrm{Mn}$ & $\mathrm{Zn}$ \\
\hline \multicolumn{6}{|c|}{ 1.Taningjam } \\
\hline & $0-20$ & 37.26 & 0.43 & 17.66 & 0.71 \\
\hline & $20-40$ & 34.47 & 0.37 & 13.12 & 0.58 \\
\hline & $40-60$ & 29.88 & 0.22 & 8.24 & 0.44 \\
\hline \multicolumn{6}{|c|}{ 2.Dailong-1 } \\
\hline & $0-20$ & 34.10 & 0.43 & 44.33 & 1.22 \\
\hline & $20-40$ & 26.31 & 0.31 & 32.01 & 0.68 \\
\hline & $40-60$ & 21.72 & 0.24 & 21.16 & 0.54 \\
\hline \multicolumn{6}{|c|}{ 3.Dailong-2 } \\
\hline & $0-20$ & 33.12 & 0.53 & 21.16 & 0.67 \\
\hline & $20-40$ & 32.33 & 0.46 & 20.17 & 0.62 \\
\hline & $40-60$ & 27.74 & 0.28 & 18.00 & 0.41 \\
\hline \multicolumn{6}{|c|}{ 4.Bhalok } \\
\hline & $0-20$ & 42.44 & 0.51 & 29.80 & 0.74 \\
\hline & $20-40$ & 37.65 & 0.41 & 13.14 & 0.40 \\
\hline & $40-60$ & 33.06 & 0.26 & 10.24 & 0.30 \\
\hline \multicolumn{6}{|c|}{ 5.Tamei Road } \\
\hline & $0-20$ & 25.00 & 0.39 & 17.84 & 0.79 \\
\hline & $20-40$ & 23.21 & 0.29 & 14.75 & 0.68 \\
\hline & $40-60$ & 18.62 & 0.12 & 12.24 & 0.50 \\
\hline \multicolumn{6}{|c|}{ 6.Kahulong-1 } \\
\hline & $0-20$ & 29.24 & 0.25 & 21.35 & 0.95 \\
\hline & $20-40$ & 27.05 & 0.25 & 19.19 & 0.65 \\
\hline & $40-60$ & 26.86 & 0.16 & 16.50 & 0.64 \\
\hline \multicolumn{6}{|c|}{ 7.Kahulong-2 } \\
\hline & $0-20$ & 37.32 & 0.48 & 13.12 & 1.32 \\
\hline & $20-40$ & 35.53 & 0.36 & 12.24 & 0.68 \\
\hline & $40-60$ & 32.94 & 0.20 & 9.72 & 0.54 \\
\hline \multicolumn{6}{|c|}{ 8.Kahulong-3 } \\
\hline & $0-20$ & 40.68 & 0.41 & 11.14 & 1.36 \\
\hline & $20-40$ & 39.89 & 0.35 & 9.19 & 1.24 \\
\hline & $40-60$ & 31.30 & 0.18 & 6.42 & 0.88 \\
\hline \multicolumn{6}{|c|}{ 9.Farmland-1 } \\
\hline & $0-20$ & 31.28 & 1.04 & 6.62 & 0.54 \\
\hline & $20-40$ & 30.49 & 0.87 & 5.24 & 0.48 \\
\hline & $40-60$ & 27.90 & 0.48 & 3.56 & 0.26 \\
\hline \multicolumn{6}{|c|}{ 10.Farmland-2 } \\
\hline & $0-20$ & 27.32 & 0.68 & 6.13 & 0.82 \\
\hline & $20-40$ & 24.13 & 0.42 & 5.97 & 0.52 \\
\hline
\end{tabular}




\begin{tabular}{|c|c|c|c|c|c|}
\hline & $40-60$ & 20.94 & 0.34 & 4.68 & 0.40 \\
\hline \multicolumn{6}{|c|}{ 11.Keikao-1 } \\
\hline & $0-20$ & 38.34 & 1.26 & 17.26 & 0.46 \\
\hline & $20-40$ & 29.15 & 0.87 & 5.24 & 0.48 \\
\hline & $40-60$ & 24.96 & 0.52 & 8.20 & 0.16 \\
\hline \multicolumn{6}{|c|}{ 12.Keikao-2 } \\
\hline & $0-20$ & 35.76 & 0.47 & 6.11 & 0.83 \\
\hline & $20-40$ & 32.97 & 0.39 & 4.14 & 0.50 \\
\hline & $40-60$ & 29.38 & 0.36 & 3.42 & 0.42 \\
\hline \multicolumn{6}{|c|}{ 13.Tamenglong Headquarter } \\
\hline & $0-20$ & 42.24 & 0.96 & 25.11 & 0.38 \\
\hline & $20-40$ & 38.55 & 0.77 & 23.47 & 0.36 \\
\hline & $40-60$ & 33.86 & 0.46 & 18.46 & 0.26 \\
\hline \multicolumn{6}{|c|}{ 14.C-Center } \\
\hline & $0-20$ & 45.12 & 1.07 & 19.38 & 0.56 \\
\hline & $20-40$ & 41.13 & 0.82 & 15.77 & 0.52 \\
\hline & $40-60$ & 32.74 & 0.50 & 11.48 & 0.28 \\
\hline \multicolumn{6}{|c|}{ 15.Azuram } \\
\hline & $0-20$ & 42.22 & 0.27 & 23.14 & 0.61 \\
\hline & $20-40$ & 38.03 & 0.20 & 15.46 & 0.34 \\
\hline & $40-60$ & 31.84 & 0.14 & 14.66 & 0.24 \\
\hline
\end{tabular}

Table.3 Effect of soil characteristics on predictability of micronutrient cations

\begin{tabular}{|c|c|c|}
\hline Depth $(\mathbf{c m})$ & Available Fe & $\mathbf{R}^{2}$ \\
\hline $0-20$ & $\begin{array}{l}173.088--27.812 \mathrm{pH}-45.515 \mathrm{EC}+ \\
3.323 \mathrm{OC}\end{array}$ & $0.501^{*}$ \\
\hline $20-40$ & $132.094+20.028 * \mathrm{OC}-23.036 \mathrm{pH}$ & $0.371 *$ \\
\hline \multirow[t]{2}{*}{$40-60$} & $20.840+12.775 \mathrm{Mg}$ & $0.293^{*}$ \\
\hline & Available $\mathrm{Cu}$ & \\
\hline $0-20$ & NS & \\
\hline $20-40$ & NS & \\
\hline \multirow{2}{*}{$40-60$} & NS & \\
\hline & Available Mn & \\
\hline 0-20 & $-11.327+24.647 \mathrm{OC}$ & $0.257^{*}$ \\
\hline $20-40$ & $-3.894+19.400 *$ OC & $0.324 *$ \\
\hline \multirow[t]{2}{*}{$40-60$} & $-1.875+18.707 * \mathrm{OC}$ & $0.249 *$ \\
\hline & Available $\mathrm{Zn}$ & \\
\hline $0-20$ & 1.287-0.076 Silt* +0.041 Clay & $0.605^{*}$ \\
\hline $20-40$ & NS & \\
\hline $40-60$ & $-0.220+0.006 \mathrm{~K}$ & $0.248^{*}$ \\
\hline
\end{tabular}


Table.4 Correlation coefficient (r) between physico-chemical properties and micronutrients of soils in $(0-20 \mathrm{~cm})$

\begin{tabular}{|c|c|c|c|c|}
\hline & $\mathbf{F e}$ & $\mathbf{C u}$ & $\mathbf{M n}$ & $\mathbf{Z n}$ \\
\hline $\mathrm{pH}$ & $-0.626^{* *}$ & -0.202 & -0.263 & 0.131 \\
\hline $\mathrm{EC}$ & $-0.527^{*}$ & -0.012 & -0.175 & 0.264 \\
\hline $\mathrm{OC}$ & $0.531^{*}$ & 0.134 & $0.507^{*}$ & 0.102 \\
\hline $\mathrm{CEC}$ & 0.175 & -0.004 & 0.043 & 0.095 \\
\hline Clay & -0.008 & -0.258 & -0.018 & $0.494^{*}$ \\
\hline Silt & -0.314 & 0.405 & -0.129 & $-0.709^{* *}$ \\
\hline Sand & -0.210 & -0.014 & 0.100 & -0.015 \\
\hline $\mathrm{N}$ & 0.069 & -0.080 & 0.067 & 0.004 \\
\hline $\mathrm{P}$ & -0.033 & -0.369 & -0.149 & 0.431 \\
\hline $\mathrm{K}$ & 0.454 & -0.016 & 0.031 & 0.237 \\
\hline $\mathrm{Ca}^{++}$ & 0.314 & -0.124 & 0.291 & 0.130 \\
\hline $\mathbf{M g}^{++}$ & 0.451 & 0.381 & 0.130 & -0.465 \\
\hline
\end{tabular}

$* \mathrm{r}$ significant at $5 \%$ level, $* * \mathrm{r}$ significant at $1 \%$ level

Table.5 Correlation coefficient $®$ between physico-chemical properties and micronutrients of soils $(20-40 \mathrm{~cm})$

\begin{tabular}{|c|c|c|c|c|}
\hline & $\mathrm{Fe}$ & $\mathrm{Cu}$ & $\mathrm{Mn}$ & $\mathrm{Zn}$ \\
\hline $\mathrm{pH}$ & $-0.513^{*}$ & 0.097 & 0.364 & 0.165 \\
\hline $\mathrm{EC}$ & 0.075 & -0.152 & -0.014 & 0.153 \\
\hline $\mathrm{OC}$ & $0.523^{*}$ & 0.001 & $0.569^{*}$ & 0.364 \\
\hline $\mathrm{CEC}$ & 0.191 & -0.017 & -0.022 & -0.014 \\
\hline Clay & -0.219 & 0.060 & 0.024 & -0.140 \\
\hline Silt & -0.132 & -0.085 & -0.413 & -0.110 \\
\hline Sand & 0.316 & -0.022 & 0.245 & 0.196 \\
\hline $\mathrm{N}$ & 0.056 & 0.025 & 0.031 & 0.094 \\
\hline $\mathrm{P}$ & -0.084 & -0.158 & -0.160 & 0.304 \\
\hline $\mathrm{K}$ & -0.289 & 0.088 & 0.093 & 0.267 \\
\hline $\mathrm{Ca}$ & 0.230 & -0.295 & 0.094 & 0.049 \\
\hline $\mathrm{Mg}$ & 0.254 & -0.045 & 0.469 & 0.268 \\
\hline
\end{tabular}

$* \mathrm{r}$ significant at $5 \%$ level, **r significant at $1 \%$ level 
Table.6 Correlation coefficient $®$ between physico-chemical properties and micronutrients of soils $(40-60 \mathrm{~cm})$

\begin{tabular}{|c|c|c|c|c|}
\hline & $\mathbf{F e}$ & $\mathbf{C u}$ & $\mathbf{M n}$ & $\mathbf{Z n}$ \\
\hline $\mathbf{p H}$ & 0.113 & 0.424 & 0.300 & -0.346 \\
\hline $\mathbf{E C}$ & 0.038 & -0.077 & 0.354 & -0.067 \\
\hline $\mathbf{O C}$ & 0.297 & -0.193 & $0.499 *$ & -0.039 \\
\hline $\mathbf{C E C}$ & 0.090 & -0.086 & 0.130 & 0.106 \\
\hline Clay & -0.221 & -0.103 & -0.261 & 0.203 \\
\hline Silt & 0.134 & 0.121 & -0.123 & -0.413 \\
\hline Sand & 0.126 & 0.025 & 0.311 & 0.051 \\
\hline $\mathbf{N}$ & 0.082 & -0.262 & 0.068 & 0.064 \\
\hline $\mathbf{P}$ & -0.139 & -0.460 & 0.286 & 0.170 \\
\hline $\mathbf{K}$ & 0.149 & 0.046 & -0.294 & $0.501 *$ \\
\hline $\mathbf{C a}^{++}$ & 0.306 & 0.068 & 0.053 & 0.210 \\
\hline $\mathbf{M g}^{++}$ & $0.542 *$ & 0.131 & 0.386 & -0.076 \\
\hline
\end{tabular}

$*_{\mathrm{r}}$ significant at $5 \%$ level, ${ }^{* *} \mathrm{r}$ significant at $1 \%$ level

It can be concluded that there exists variation in soil properties with respect to depth in soil profiles. The surface layer soils were fairly high in organic carbon and adequate in all the micronutrients content. But the content of all the nutrients were low in the sub-surface layers especially from $40 \mathrm{~cm}$ to $60 \mathrm{~cm}$ depth as compared to the surface layers in all the studied areas. As compared to other micronutrients, the $\mathrm{Zn}$ content of the lower layers was found to be more deficient in many samples. The macronutrient content of most the sample varies from low to medium in all the profile. This may be an important reason for decreasing production potential of orange in Tamenglong district of Manipur. Moreover, the lack of fertilization practice results in soil fertility depletion in the long run as well as the demand cannot be supplied. It is of great importance to replenish the nutrient content of the soil and to maintain balanced fertilization for proper crop production. Therefore, it is advisable to apply $\mathrm{Cu}$ and $\mathrm{Zn}$ along with macronutrients to sustain the fertility of the soils as well as productivity of crop to increase the income of the farming community.

\section{References}

Athokpam, H., Wani, S.H., Kamei, D., Athokpam, H.S., Nongmaithem, J., Kumar, D., Singh, Y.K., Naorem, B.S., Devi, T.R. and Devi, L. (2013). Soil macro- and micro-nutrient status of Senapati district, Manipur (India). African Journal of Agricultural Research. 8(39): 4932-4936.

Athokpam, H.S., Singh, K.S., Chongtham, N., Devi, K.N., Singh, N.B., Sanatomba, A. and Sharma, P.T. (2018). Vertical distribution of micronutrient cations in Imphal east and west district, Manipur (India). International Journal of Current Microbiology and Applied Sciences. 7(8): 4222-4227.

Athokpam, H.S., Vikramjit, K., Chongtham, N., 
Devi, K.N., Singh, N.B., Singh, N.G., Sharma, P.T. and Heisnam, P. (2018). Micronutrient cations distribution in the soil profile of orange (Citrus reticulata) orchard of Tamenglong district, Manipur (India). Journal of Experimental Biology and Agricultural Sciences. 6(1): 108-115.

Athokpam, H.S., Zimik, V.S., Chongtham, N., Devi, K.N., Singh, N.B., Watham, L., Sharma, P.T. and Athokpam, H. (2016). Profile distribution of micronutrient cations in citrus orchard of Ukhrul district, Manipur (India). International Journal of Agriculture, Environment and Biotechnology. 9(4): 691-697.

Bell, R.W. and Dell, B. (2008). Micronutrients for sustainable food, feed, fibre and bioenergy production. $1^{\text {st }}$ edn. IFA, Paris, France.

Borah, D.K., Bordoloi, P.K., Karmakar, R.M., Baruah, N.G. and Das, M. (1987). Practical Manual for Fundamental of Soil Science (Part-III), Jorhat, Assam.

Bouyoucos, G.J. (1951). Soil Science. 23: 319343.

Bray, R.H. and Kurtz, L.T. (1945). Determination of total, organic and available forms of phosphorus in soils. Soil Sci., 59: 39-45.

Chopra, S.L. and Kanwar, J. 1976. Analytical Agricultural Chemistry. Kalyani Publishers, Ludhiana, Punjab, India.

Gao, S., Yan, R., Cao, M., Yang, W., Wang, S. and Chen, F. (2008). Effect of on growth, antioxidant enzymes and phenylalanine ammonia-lyase activities in Jatropha curcas L. seedling. Plant Soil and Environment. 54(3): 117-122.

Gupta, N., Trivedi, S.K., Bansal, K.N. and Kaul, R.K. (2003). Vertical distribution of micronutrient cations in some soil series of northern Madhya Pradesh. Journal of the Indian Society of Soil Science. 51(4): 517-522.

Jackson, M.L. (1973). Soil Chemical Analysis. Prentice-Hall of India Pvt. Ltd. New Delhi.

Kumar, T.V., Reddy, M.S., and Krishna, V.G.
(1996). Vertical distribution of micronutrient cations in some soil profiles of Northern Telangana of Andhra Pradesh. Journal of the Indian Society of Soil Science. 44(2): 328-330.

Lindsay, W.L. and Norvell, W.A. (1978). Development of DTPA soil test for zinc, iron, manganese and copper. American Journal of Soil Science. 42: 421-428.

Murthy, I.Y.L.N., Sastry, T.G., Dutta, S.C., Narayanasamy, G. and Rattan, R.K. (1997). Distribution of micronutrient cations in vertisols derived from different parent material. $J$. Journal of the Indian Society of Soil Science. 45(3): 577-580.

Panse, V.G. and Sukhatme, P.V. (1985). Statistical Methods for Agricultural Workers. ICAR, New Delhi.

Pati, R. and Mukhopadhyay, D. (2011). Distribution of cationic micronutrients in some acid soils of West Bengal. Journal of the Indian Society of Soil Science. 59(2): 125-133.

Rajkumar, Nayyar, V. K., Sidhu, G. S. and Deshmukh, S. N. (1990). Distribution of available micronutrient cations in some dominant soil series in different physiographic units of Bundelkhand region of Madhya Pradesh. Journal of the Indian Society of Soil Science. 38: 410-415.

Rattan, R.K., Patel, K.P., Manjaiah, K.M. and Datta, S.P. (2009). Micronutrients in soil, plant, animal and human health. Journal of the Indian Society of Soil Science. 57(4): 546-558.

Rengel, Z. (2007). Cycling of micronutrients in terrestrial ecosystems. In: Marschner, P. and Rengel, Z. (Eds.) Nutrient Cycling in Terrestrial Ecosystem. SpringerVerlag, Berlin, Heidelberg, pp. 93-121.

Sakar, D., Baruah, U., Gangpadhyay, S.K., Sahoo, A.K. and Velayutham, M (2002). Characteristics and classification of soils of Lotak catchment area of Manipur for sustainable land use planning. Journal of the Indian Society of Soil Science. 
50(2): 196-204.

Satyavathi, P.L.A. and Reddy, M.S. (2004). Distribution of DTPA extractable micronutrient in soils of Telengana, Andhra Pradesh, Agropedology. 14(1): 32-37.

Sen, T.K., Dubey, P.N., Maji, A.K. and Chamuah, G.S. (1997). Status of micronutrients in some dominant soils of Manipur. Journal of the Indian Society of soil Science. 45(2): 388-390.

Sharma, P.D. (2008). Nutrient management challenges and options. Journal of the Indian Society of Soil Science. 55: 395403.

Sharma, R.P., Singh, M. and Sharma, J.P. (2003). Correlation studies on micronutrients vis-à-vis soil properties in some soils of Nagaur district in semiarid region of Rajasthan. Journal of the Indian Society of Soil Science. 51(4): 522-527

Singh, K.S. and Athokpam, H. (2018). Physicochemical characterization of farmland soil in some villages of Chandel hill district, Manipur (India). International Journal of Current Microbiology and Applied Sciences. 7(2): 417-425.

Singh, L.P., Athokpam, H.S., Chongtham, N., Devi, K.N., Singh, N.B., Sanatomba, A., Singh, N.G. and Sharma, P.T. (2018). Vertical distribution of micronutrient cations in Thoubal and Bishnupur district, Manipur (India). International Journal of Current Microbiology and Applied Sciences. 7(9): 2178-2183.
Singh, M.V. (2004). Micronutrient deficiencies in Indian soils and field usable practices for their correction. IFA International Conference on Micronutrients, New Delhi.

Srivastava, A. K. and S. Singh, (2002a). World citrus: Climate and soil analysis. In Citrus: Climate and soil. Eds.1-2902. International Book Distributing Co., Lucknow, Uttar Pradesh, India.

Srivastava, A. K. and S. Singh, (2002b). Soil analysis based diagnostic norms for Indian citrus cultivar. Communication in Soil Science and Plant Analysis. 33: 1689-1706.

Srivastava, P.P, Pandiaraj, T., Das, S. and Sinha, A.K. (2017). Assessment of micronutrient status of soil under Tasar host plant growing regions in Jashpur district, Chhattisgarh State. Imperial Journal Interdisciplinary Research. 3: 1080-1083.

Subbiah, B.V. and Asija, G.L. (1956). A rapid procedure for estimation of available $\mathrm{N}$ in soils. Current Sciences. 25: 259-260

Verma, V.K., Setia, R.K., Sharma, P.K. (2007b). Distribution of micronutrient cations in different physiographic units of semi-arid region of Punjab. Agropedology. 18: 58-65.

Walkley, A. and Black, C.A. (1934). An examination of the method for determining soil organic matter and a proposed modification of the chromic acid titration method. Soil Science. 37(16): 29-39.

\section{How to cite this article:}

Laikhuram Banarjee Singh, Herojit Singh Athokpam, Rajkumar Kumarjit Singh, K. Nandini Devi, Edwin Luikham and Okendro Singh, N. 2019. Vertical Distribution of Micronutrient Cations in the Orange (Citrus reticulata) Orchard, Tamenglong District, Manipur (India). Int.J.Curr.Microbiol.App.Sci. 8(07): 1166-1177. doi: https://doi.org/10.20546/ijcmas.2019.807.138 